\title{
Hevosalan nykytila, haasteet ja tutkimustarpeet
}

\author{
Markku Saastamoinen \\ MTT Kotieläintuotannon tutkimus, hevostalous, Opistontie 10 a, 32100 Ypäjä, markku.saastamoinen@mtt.fi
}

\section{Tiivistelmä}

Hevostalous on ainoa kotieläintuotannon ala, joka kasvaa. Kaikissa EU-maissa on nähtävänä samankaltainen hevosalan kehitys, myös niissä, joissa se on jo entuudestaan merkittävää toimintaa. Hevosia on Suomessa noin 75 000, ja määrä lisääntyy vuosittain noin tuhannella. Hevosen voidaan arvioida vaikuttavan lähes 500000 henkilön elämään elinkeinotoiminnan, harrastuksen ja hevosenomistuksen kautta.

Hevosalan yritystoiminnasta Suomessa kolme neljäsosaa tapahtuu maaseudulla. Hevosala työllistää meillä koko- tai osa-aikaisesti 15000 - 16000 ihmistä. Koko EU:n alueella alan työllistävä vaikutus on 300000 henkilöä. Euroopan eri maissa työllisyysvaikutuksen arvioidaan olevan yksi ihminen 3 - 10 hevosta kohti.

Maaseudun yritys- ja elinkeinotoiminnan monipuolistamisessa voimakkaasti kasvava hevostalous eri toimintamuotoineen on merkittävä mahdollisuus. Hevosrehujen tuotanto ja hevosten omistajille ja hevosharrastajille tarjottavat palvelut ovat tästä esimerkkejä. Myös hevostoiminnassa käytettävien tarvikkeiden tuotannosta voi syntyä maaseudulle ja maatiloille pienyritystoimintaa.

Alan nopea kasvu tuo mukanaan paljon haasteita. Sekä harrastaja- että yrittäjäjoukkoon tulee jatkuvasti uusia ihmisiä, joiden kokemustausta sekä alasta että hevosista on entistä vähäisempi. Tämä ei ole ongelma yksin Suomessa, vaan kaikkialla Euroopassa ja Yhdysvalloissa. Hevosalan keskeiseksi yhteiskunnalliseksi ja ympäristöhaasteeksi ovat nousseet maankäyttökysymykset. On luonnollista, että talliyritykset sijoittuvat lähelle asiakkaitaan, jolloin hevosilla liikutaan lähellä asutusta ja muuta elinkeinotoimintaa. On lisäksi tyypillistä, että monille alueille on syntynyt talliyritysten keskittymiä, jolloin hevosten ympäristövaikutukset kasvavat huomattavasti.

Hevosalan toimijoiden huolenaiheena ja yhteisenä haasteena on ollut alan huono tuntemus ja arvostuksen puute viranomaisten ja muun yhteiskunnan taholta tai osana maataloussektoria. Hevostalouden merkitystä ja esimerkiksi työllistävää ja sosiaalisia vaikutuksia ei tunneta ja tunnusteta edelleenkään riittävästi. Tämä näkyy mm. tutkimusrahoituksen suuntaamisessa.

Hevosalan tutkimus- ja kehittämistoiminnassa korostuvat erityisesti hevosten hyvinvointiin liittyvä tutkimus sekä alan yhteiskunnallisen ja taloudellisen merkityksen tutkimus. Myös ympäristöasiat ovat keskeisessä roolissa. Yhteiskunnallinen tutkimus on tärkeätä kehitettäessä ohjaustoimia, jotka mahdollistavat hevosalan taloudellisen ja hyvinvointipoliittisen potentiaalin saamisen käyttöön laajasti yhteiskunnassa. Sen avulla alan näkemykset välittyvät yhteiskunnallisiin päätöksiin ja päätöksentekijät saavat tutkittua tietoa päätöksenteon tueksi. Hevostutkimuksessa kansainvälinen yhteistyö tulee lisääntymään, koska kasvavan alan haasteet ovat eri maissa samankaltaisia. On tärkeätä, että hevostalous otetaan osaksi EU:n maaseutupolitiikkaa ja sen puiteohjelmia.

Jatkossa hevosala tulee ottaa paremmin huomioon myös Suomessa yliopistotasoisessa opetuksessa ja tutkijakoulutuksessa. Hevosalan tutkimus-, kehittämis-, opetus- ja erilaiset asiantuntijatehtävät tarvitsevat alan yliopistotutkinnon suorittaneita osaajia.

Asiasanat: hevonen, hevostalous, maaseutu, hevostutkimus 


\section{Johdanto}

Hevoskasvatus ja -urheilu ovat jakaantuneet verraten tasaisesti koko maahan ja hevosen voidaan arvioida vaikuttavan lähes 500000 henkilön elämään elinkeinotoiminnan, harrastuksen ja hevosenomistuksen kautta. Suomessa ratsastuksen harrastajien määräksi arvioidaan 120 000. Raviurheilua seuraa säännöllisesti 250000 - 300000 henkilöä, mistä syntyvä vuotuinen hevospelivaihto nousee 250 miljoonaan euroon. Hevosenomistajia arvioidaan olevan 35000.

Hevosia on Suomessa noin 75 000, ja niiden määrä lisääntyy vuosittain noin tuhannella. Määrän kasvu on suurinta ratsuhevosten ja ponien kohdalla. Jo nyt yli puolet hevosistamme on ratsastuskäytössä. Hevosten osuus myös sosiaalipedagogisessa toiminnassa ja hyvinvointipalveluiden tuottamisessa on kasvanut. Talliyhteisöt tekevät myös merkittävää nuorisotyötä.

Hevostalous on voimakkaasti kasvava ja työvoimavaltainen ala, joka kiinnostaa etenkin nuoria, ja jonka vaikutukset näkyvät sekä maaseudulla että kaupungeissa ja taajamissa. Se lisää maaseutukaupunkivuorovaikutusta monin tavoin. Hevosala rakentuu eri hevosmaissa kutakuinkin samalla tavalla, ja haasteet ovat niin ikään samankaltaisia. Nämä liittyvät mm. maankäyttöön, yritystoiminnan kannattavuuteen ja eläinten hyvinvointiin. Hevosala on muodostumassa merkittäväksi kohteeksi eri maiden maaseutupolitiikassa.

\section{Alan kasvu jatkuu}

Hevostalous on ainoa kotieläintuotannon ala, joka kasvaa, minkä vuoksi sillä on suuri merkitys suomalaiselle maaseudulle. Paitsi kasvava, se on myös tukiriippumaton ala. Kaikissa EU-maissa on nähtävänä samankaltainen hevosalan kehitys - myös niissä maissa, joissa se on jo entuudestaan merkittävää toimintaa.

Yritysmäisesti toimivia ratsastus-, ravi- ja maatilatalleja arvioidaan Suomessa olevan runsas 3000, ja kaikkiaan talleja on noin 16000 . Ne harjoittavat hevoskasvatusta tai tarjoavat hevosalan palveluita, kuten hevosten valmennusta, koulutusta, hoitopalveluita, ratsastustunteja tai hevosmatkailua. Talliyritykset ja muu hevosala työllistävät noin 5000 henkilöä kokopäiväisesti, minkä lisäksi hevosalalla tarvittavat palvelut ja kauppa sekä rehujen tuotanto työllistävät 1000 henkilöä. Osa-aikaisesti alalla työskentelee lisäksi noin 10000 ihmistä. Vertailun vuoksi voidaan todeta, että bioenergia-alan on arvioitu työllistävän tulevaissudessa yhteensä noin 12000 ihmistä. Biotekniikkayrityksissä työskentelee noin 4000 henkilöä - koko lääketeollisuus mukaan lukien noin 11 000. Koko EU:n alueella hevostalous antaa työtä 300000 ihmiselle, mikä edustaa 2,4 \% koko maataloussektorin työpaikoista.

Hevosalalle arvioidaan syntyvän viiden vuoden kuluessa yli 1000 uutta yritystä, jotka tulevat työllistämään yrittäjien lisäksi 250 - 500 henkilöä, enimmäkseen maaseudulla, jossa pääosa talliyrityksistä toimii. Hevosalan työllistäväksi vaikutukseksi arvioidaan meillä, että 8 - 10 hevosta luovat yhden työpaikan, mutta maaseudun talleissa kymmentä hevosta kohti työskentelee keskimäärin kaksi henkilöä. Euroopan eri maissa työllisyysvaikutuksen arvioidaan olevan yksi ihminen $3-10$ hevosta kohti. Kasvava hevostalous luokin jatkuvasti uusia työpaikkoja menetettyjen tilalle.

Viime vuosina uusia talleja ja ratsastushalleja on rakennettu runsaasti, mihin hevostalouden investointituilla on ollut merkittävä vaikutus. Toimintaympäristöön kohdistuneiden investointeihin arvioitiin vuosien 2000 - 2005 välisenä aikana käytetyn noin 100 miljoonaa euroa, mikä on suuruudeltaan 50 - 75 \% vastaavana aikana tehdyistä sikalainvestoinneista ja 30 - 40 \% navettainvestoinneista. Investoinnit jatkuivat alalla edelleen tämän jälkeenkin, ja halukkuutta niiden tekemiseen ja toiminnan laajentamiseen näyttäisi olevan edelleen.

\section{Mahdollisuus maaseudulle}

Hevosalan yritystoiminnasta 75 \% tapahtuu maatiloilla ja 17 \% muutoin maaseudulla. Hevostaloutta harjoitetaan noin 2000 maatilalla, mutta kaikkiaan hevosia pidetään tätä nykyä noin kuudella tuhannella tilalla. Tämä määrä tuskin tulee vähenemään siinä tahdissa, missä maatilojen määrä maassamme edelleen vähenee viimeisimpien ennusteiden mukaan Suomessa tulee olemaan kymmenen vuoden kuluessa noin 35000 maatilaa, joista kotieläintiloja ainoastaan 7000 .

Suurin osa hevosalan yritystoiminnasta tapahtuu taajamien ja kaupunkien läheisellä maaseudulla mahdollisimman lähellä asiakkaita. Hevoskasvatusta harjoitetaan myös syvemmällä maaseudulla. Sidos maaseutuun, sen elinkeinoihin ja maatalouteen tulee myös rehuntuotannon kautta. Yksi hevonen tarvitsee 
rehuntuotantoon ja laiduntamiseen noin 1 - 1,5 ha peltoa, mikä tarkoittaa siis noin 75000 - 100000 ha rehuntuotantoalaa (n. 5 \% Suomen peltoalasta). Pääosa talleista hankkii rehut viljelijöiltä, esimerkiksi yli 70 \% Etelä-Suomen talleista ostaa kaiken tarvitsemansa rehun tilan ulkopuolelta. Yksi hevonen "ostaa” maataloutemme tuotantoa noin 1,5 eurolla päivässä. Kokonaisvolyymiltään tämä vastaa yli 200000 suomalaisen kuluttamaa maataloustuotantomme määrää. Hevonen ei siis ole pelkkä maaseudun maisemanhoitaja.

Maaseudun yritys- ja elinkeinotoiminnan monipuolistamisessa voimakkaasti kasvava hevostalous eri toimintamuotoineen on merkittävä mahdollisuus. Hevosrehujen tuotanto ja hevosten omistajille ja hevosharrastajille tarjottavat palvelut ovat tästä esimerkkejä. Myös hevostoiminnassa käytettävien tarvikkeiden tuotannosta voi syntyä maaseudulle ja maatiloille pienyritystoimintaa.

Hevostalous liittyy usein maatilojen monialaisuuteen. ProAgrian asiakasrekisterin mukaan sen yritysneuvonnan asiakkaista suurimman ryhmän muodostavat hevosalan yritykset - suuremman kuin koneurakoinnin, sosiaali- ja terveysalan, maaseutumatkailun ja elintarvikealan yritykset yhteensä. Hevosalan kasvu tuo mahdollisuuksia lisäksi muille toimialoille, kuten rakentaminen, varuste- ja tarvikekauppa, eläinlääkintäja kengitystoiminta.

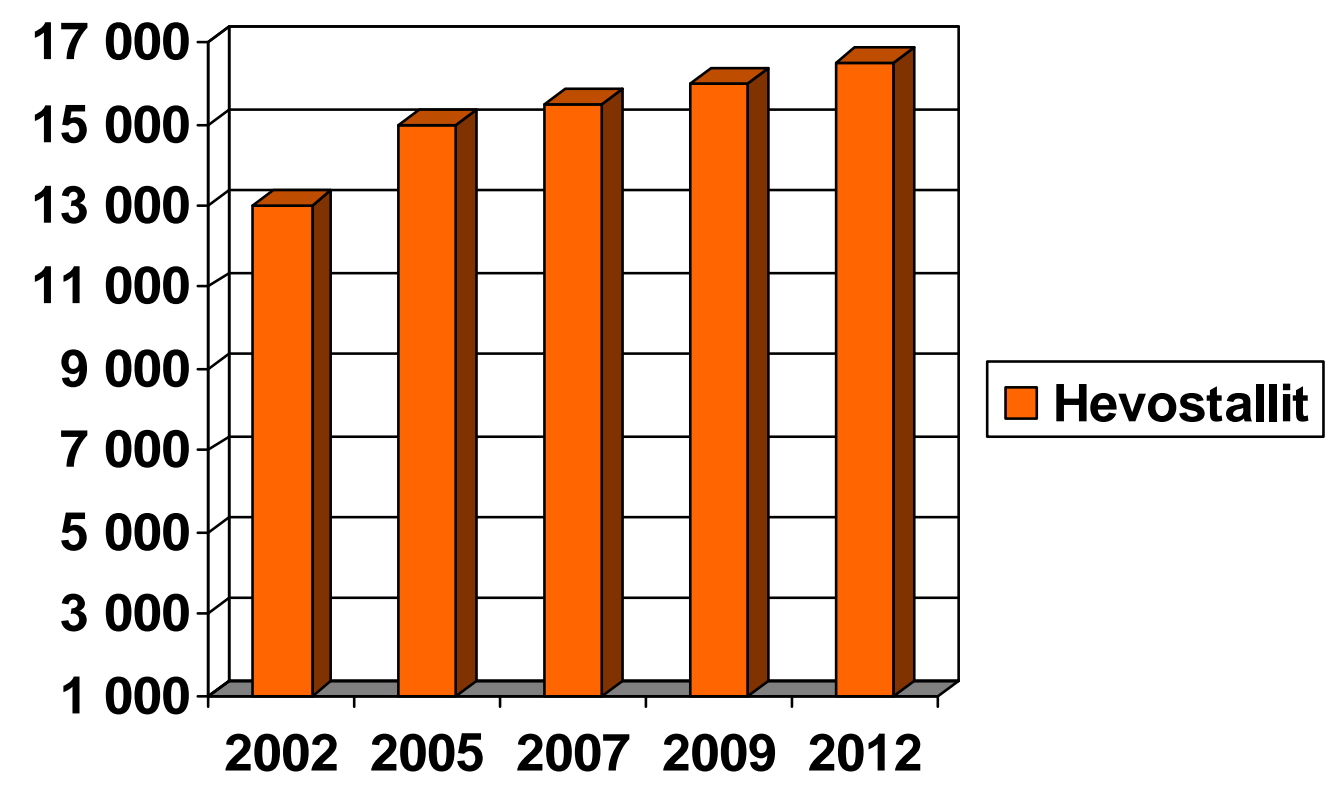

Kuva 1. Hevostallien lukumäärä Suomessa vuosina 2002 ja 2005 sekä määrän arvioitu kasvu vuoteen 2012 (MTT hevostalous)

\section{Kasvu tuo haasteita}

Alan nopea kasvu tuo mukanaan paljon haasteita. Sekä harrastaja- että yrittäjäjoukkoon tulee jatkuvasti uusia ihmisiä, joiden kokemustausta sekä alasta että hevosista on entistä vähäisempi. Tämä ei ole ongelma yksin Suomessa, vaan kaikkialla Eurooppaa ja Yhdysvalloissa. Asioiden tekeminen oikein alusta alkaen on tärkeätä alan imagolle.

Ihmisten kohdalla suurimmat ongelmat tässä liittyvät turvallisuuteen oli sitten kysymys työstä tai harrastuksesta hevosten parissa. Suurikokoisen eläimen kanssa toimiminen voi aiheuttaa monia vaaratilanteita, kun eläintä ei tunneta, se on puutteellisesti koulutettu tai ei yhteistyö ihmisen ja eläimen välillä ei vain suju. Hevosen näkökulmasta ongelma liittyy hyvinvointikysymykseen - riittääkö uusilla toimijoilla osaaminen hevosten käsittelyyn ja niiden tarpeiden tyydyttämiseen. Hevosten hyvinvoinnista huolehtiminen - mukaan lukien hevosen lopettaminen - on yksi keskeisistä hevosalan julkikuvaan vaikuttavista tekijöistä. Yrittämisen kohdalla ongelmana voi olla heikko yrittäjäosaaminen - intoa harrastuksen pohjalta on usein enemmän kuin taitoa. Myös yrittäjien jaksamiseen työvoimavaltaisella alalla on kiinnitettävä huomiota. 
Neuvontapalveluita eivät hevosalan yritystoiminnan harjoittajat vielä kovin laajasti käytä - sen sijaan erilaiset alan koulutustilaisuudet kokoavat suuria sekä yrittäjistä, yrittäjiksi aikovista että harrastajista koostuvia kuulijajoukkoja. Hevosalalle on paikallaan räätälöidä omia yritysneuvonnan muotoja, joissa voidaan huomioida yritysten erityispiirteet ja yrittäjien taustat, jotka usein löytyvät vankasta harrastuspohjasta. Hevosalan yritykset ovat usein kooltaan pieniä - suurimmat löytyvät luonnollisesti alueilta, joilla on laaja väestö- ja asiakaspohja.

Hevoskasvatus ja -urheilu kansainvälistyivät nopeasti. Kansainvälistyminen aiheuttaa haasteita kilpailutoiminnalle ja yhteisille tavoitteille etenkin hevosurheilun doping-puhtauden takaamiseksi ja urheilun eettisten kysymysten huomioon ottamiseksi. Myös hevosjalostus kansainvälistyy, ja jalostustavoitteet yhdenmukaistuvat; yhteistyötä on tehtävä jalostusarvostelussa, mistä esimerkkinä on ratsuhevosjalostuksessa usean maan yhteinen arvostelu, Interstallion. Urheilun ja jalostuksen välinen yhteistyö niin kansainvälisellä kuin kansallisella tasolla on tärkeätä. Myös jalostukseen kansainvälistyessä esiin nousevat eettiset ja eläinten hyvinvointia korostavat asiat.

Kansainvälistymisessä kasvavia haasteita ovat myös kotimaisen kasvatuksen ja ravitoiminnan kilpailukyvyn säilyttäminen. Tämä edellyttää kotimaista kasvatusta ja menestystä valmennus- ja jalostustoiminnassa, joissa voidaan sanoa olevan hevosalan ja sen eri toimintojen kehittymisen perusta. Maamme hevoskasvatuksesta yli $80 \%$ tapahtuu maatiloilla.

Hevosalan keskeiseksi yhteiskunnalliseksi ja ympäristöhaasteeksi ovat nousseet maankäyttökysymykset. On luonnollista että talliyritykset sijoittuvat lähelle asiakkaitaan, jolloin hevosilla liikutaan lähellä asutusta ja muuta elinkeinotoimintaa. On lisäksi tyypillistä, että monille alueille on syntynyt talliyritysten keskittymiä, jolloin hevosten ympäristövaikutukset kasvavat huomattavasti. Hevonen tarvitsee tilaa päivittäiseen ulkoiluun, ja talliyrityksen toimintaympäristö yleensäkin on laaja. Rakennukset, tarhat, ajoreitit ja ratsastuskentät voivat huonosti hoidettuina muodostua ympäristön pilaajiksi. Ilman kaikki osapuolet huomioon ottavaa huolellista sääntelyä tallien ja hevosalueiden rakentamisesta taajamien läheisyyteen syntyy helposti lamauttavia konflikteja ja erimielisyyksiä.

Oman lukunsa muodostaa hevosen lanta, jonka jatkokäsittely saattaa tuottaa talleille ongelmia, vaikka se voi parhaimmillaan ollakin energianlähde. Poistettavien ja kuolleiden hevosten käsittely on niin ikään puhuttanut jo useita vuosia - vain pieni osa hevosista päätyy teuraaksi ja elintarviketuotantoon, minkä sijaan hevosenlihaa tuodaan Suomeen yli miljoona kiloa vuodessa. Teurastamisen lisäksi hevonen voidaan hävittää Suomessa pääkaupunkiseutua lukuun ottamatta edelleen myös hautaamalla.

Hevosalan toimijoiden huolenaiheena ja yhteisenä haasteena on ollut alan huono tuntemus ja arvostuksen puute viranomaisten ja muun yhteiskunnan taholta tai osana maataloussektoria. Hevostalouden merkitystä ja esimerkiksi työllistävää ja sosiaalisia vaikutuksia ei tunneta ja tunnusteta edelleenkään riittävästi. Hevosalan toimijoiden on jatkuvasti työskenneltävä yhteistyössä kuntien sekä maatalous-, elinkeino- ja ympäristöviranomaisten kanssa, jotta alan erityispiirteet tulevat riittävästi huomioiduiksi suunnittelussa ja päätöksenteossa. Muun muassa ympäristövaikutuksiin ja maankäyttöön liittyvät tekijät eroavat maaseudulla tiheään asutuista alueista.

Käytännön yhteistyötoimilla ja erilaisten tutkimus- ja kehityshankkeiden avulla on mahdollisuus lisätä alan legimiteettiä. Jotta hevosalan kasvua voidaan hyödyntää hallitusti yhtä hyvin maaseudun yritystoiminnassa kuin nuorisotyössäkin, on tärkeää, että toiminta tapahtuu kestävällä ja osaavalla pohjalla. Tähän tarvitaan hevostalouteen kohdistuvaa tutkimusta sekä koulutuksen, neuvonnan ja tiedonsiirron kehittämistä. Myös tutkimuksen suuntaamiseen tarvitaan tutkittua tietoa.

Hevosalaa rahoitetaan merkittävästi hevospelien (vedonlyönti) tuotoista - yhteensä EU-maissa tämä rahoitus on 1,5 miljardia euroa vuodessa. Siksi on tärkeätä, että yksinoikeuteen perustuva rahapelijärjestelmä säilyy. Eri maiden yhteinen huolenaihe on rahapelien asema ja hoitaminen kussakin maassa ja koko EU:n alueella. Kansainvälisissä hevosalan kongresseissa on myös katsottu, että hevosalan on päästävä paremmin hyödyntämään lisäksi muita, erityisesti EU:n rahoituslähteitä sekä tutkimuksessa että alan yritys- ja kehitystoiminnassa. Jotta hevonen voi säilyttää asemansa ja merkityksensä osana maaseutua, on kansainvälisissä yhteyksissä painotettu myös sitä, että hevosen on sälytettävä tuotantoeläimen statuksensa.

\section{Tutkimukselle tarvetta}

Hevosalan tutkimus- ja kehittämistoiminnassa korostuvat erityisesti hevosten hyvinvointiin liittyvä tutkimus sekä alan yhteiskunnallisen ja taloudellisen merkityksen tutkimus. Myös ympäristöasiat ovat keskeisessä 
roolissa. Hyvinvointikysymysten ratkaisemiseen liittyy läheisesti valmennus- ja ravitsemusfysiologinen tutkimus sekä olosuhde- ja rakentamistutkimus.

Tutkimustoimintaa ja tutkimustarpeita käsittelevissä viimeisimmissä kansainvälisissä seminaareissa hevostutkimuksen alat on eroteltu "perinteisiin” ja "uusiin”. Ensiksi mainittuihin kuuluvat biologisen tutkimuksen piiriin lukeutuvat hevosten ravitsemus, jalostus, käyttäytyminen ja hyvinvointi, urheilulääketiede sekä lisääntyminen. Uusia tutkimushaasteita syntyy ympäristökysymyksistä kuten hevosen lannankäytöstä ja käsittelystä, peltojen monimuotoisuudesta sekä ilmaston lämpenemiseen liittyvistä kysymyksistä. Teknisellä ja sosio-ekonomisella tutkimuksella voidaan vaikuttaa EU:n ja kansallisiin politiikkoihin (esim. eläinsuojelu, yhteiskunnallinen vaikutus). Nämä ovat aiheita, joihin myös suomalaista tutkimusta on haluttu viime vuosina suunnata.

Yhteiskunnallinen tutkimus on tärkeätä kehitettäessä ohjaustoimia, jotka mahdollistavat hevosalan taloudellisen ja hyvinvointipoliittisen potentiaalin saamisen käyttöön laajasti yhteiskunnassa. Sen avulla alan näkemykset välittyvät yhteiskunnallisiin päätöksiin ja päätöksentekijät saavat tutkittua tietoa, jota he tarvitsevat päätettäessä muun muassa alan tuista ja verotuksesta yhtä hyvin kuin taajamien läheisyyteen rakennettavien tallien ja hevosalueiden ympäristö- ja maankäyttökysymyksistäkin.

Hevosalan yritystoiminta Suomessa on pääosin nuorta - aloittaminen on tapahtunut yleensä 1990- ja 2000-luvuilla. Yritystoimintaan liittyvä taloustutkimus onkin nähty meillä tarpeelliseksi. Hevosalan palveluiden kysynnän kasvaessa pienten hevostalousyritysten määrä lisääntyy, jolloin yrittäjän liiketalousosaaminen, palveluiden laatu, hinnoittelu, asiakaskeskeisyys ja markkinointitaidot eivät aina vastaa alan kasvavaan kysyntään. Yritysten talouden kehittämisen perustana on työn- ja pääomankäytön sekä muiden kannattavuuteen liittyvien tekijöiden tunteminen.

Kun yritysten toiminta on taloudellisesti kestävällä pohjalla, yrityksissä voidaan huomioida paremmin sosiaalisesti, eettisesti ja ympäristön kannalta kestävän kehityksen asettamat vaatimukset. Taloustutkimuksen tuottama tieto lisää alan merkityksen tunnistamista päättäjien keskuudessa ja laajasti yhteiskunnassa. Tutkimuksella voidaan saada uutta tietoa hevosalan harrastepalveluita käyttävistä asiakasryhmistä ja heidän erilaisista ja muuttuvista tarpeistaan, jolloin alan yrittäjät voivat kehittää eri kuluttajille paremmin sopivia tuotteita ja palveluita.

Hevostaloutta on tarvetta tutkia myös sosiologisesta näkökulmasta, sillä kyse on laajoja väestöryhmiä koskevasta harrastuksesta ja sen lisääntymisestä. Vaikka ratsastus usein mielletään nuorten tyttöjen harrastukseksi, enemmistö alan harrastajista on aikuisväestöön kuuluvaa. Tutkimuksen kautta voidaan valottaa kysymystä sukupuolten ja eri väestöryhmien tasa-arvoisuudesta harrastusmahdollisuuksien sekä yhteiskunnan tukimuotojen tasa-arvoisuudesta osalta maaseudulla ja taajama-alueilla. Oma itsenäinen haasteensa on hevosen ja ratsastuksen merkitys eri väestöryhmien terveydelle ja tämän ylläpitämisessä.

Vain kansallinen hevostutkimus voi tuottaa tietoa Suomen ilmasto-oloihin soveltuvista pito- ja käyttöolosuhteista, valmennusmenetelmistä ja ilmasto-olojen vaikutuksista esimerkiksi tammojen tiinehtyvyyteen. Samoin pitkä sisäruokintakautemme asettaa vaatimuksia rehujen laadulle ja talliolosuhteille. Myös suomenhevonen erityispiirteineen vaatii menestyäkseen kansallisia tutkimuspanoksia.

Hevostutkimuksen rahoitukselle ei meillä ole olemassa sen jatkuvuuden ja korkean tason takaavaa järjestelmää. Nykyisissä rahoituslähteissä ja niiden ohjelmissa ei ole huomioitu tätä kasvavaa toimialaa, eikä sitä ole pidetty "uskottavana” tai "kiinnostavana”, kuten joissakin kielteisissä rahoituspäätöksissä on perusteltu. Ruotsissa ja Norjassa on hevosalan ja maatalousalan toimijoiden ja valtion (maatalousministeriöt) yhteistyönä luotu rahoitusjärjestelmä, jolla rahoitetaan pelkästään hevoshankkeita merkittävällä summalla vuodessa. Samalla valtio (yliopistot) ylläpitää tarvittavia resursseja tutkimukselle. Monissa maissa ohjataan Suomen tapaan totalisaattorivaroja hevostutkimukseen.

Hevostutkimuksessa kansainvälinen yhteistyö tulee lisääntymään, koska kasvavan alan haasteet ovat eri maissa samankaltaisia. On tärkeätä, että hevostalous otetaan osaksi EU:n maaseutupolitiikkaa ja sen puiteohjelmia - tukeehan hevostalous erinomaisesti EU:n maaseutupolitiikan tavoitteita. Kotimainen rahoitus on turvattava, jotta kansainvälisille rahoituslähteille voidaan pyrkiä. Yhteistyötä ja tutkimuksen kotimaista rahoitusta suunniteltaessa on huomattava, että alan yritykset ovat meillä enimmäkseen hyvin pieniä, ja niillä on varsin rajalliset mahdollisuudet osallistua tutkimusrahoitukseen.

Kansallisessa hevostutkimusohjelmassa, jonka hevosala ja tutkimuslaitokset laativat yhteistyönään MMM:n pyynnöstä vuonna 2005, nimettiin seuraavat painopistealat hevostutkimukselle:

(1) Hevoskasvatuksen edellytysten parantaminen 
Läpäisevänä taustateemana on hevosen hyvinvointi, joka kytkee yhteen terveyteen ja hevosten pitoon liittyviä tekijöitä.

(2) Hevostalous

Tutkimus tukee hevosalan yritystoiminnan kilpailukykyä ja vahvistaa sen merkitystä kansantaloudessa.

(3) Hevosala osana yhteiskuntaa

Tutkimus käsittelee ihmisen ja hevosen vuorovaikutusta sekä hevostoiminnan ja yhteiskunnan välisiä suhteita.

\section{Koulutus ja neuvonta tärkeitä kehittää}

Hevosalan koulutuksessa on Suomessa panostettu ammatilliseen koulutukseen. Koulutusta antaa tätä nykyä yhdeksän oppilaitosta. Hevosalalla on myös ammattikorkeakoulututkinto, hevosagrologi-AMK, johon johtavaa koulutusta annetaan kahdessa ammattikorkeakoulussa. Näin on turvattu hyvin työvoiman tarve mm. alan yrityksille ja kaupalle.

Hevosalan yliopistokoulutusta ei sen sijaan erityisesti anneta, eikä yliopistoilla ole hevosiin suuntautuvia koulutusohjelmia, kuten monessa muussa maassa jo nykyisin on (Equine Science, Equine Studies). Esimerkiksi Ruotsin maatalousyliopisto (SLU) Uppsalassa kutsuu itseään "hevosyliopistoksi”. Meillä hevosiin liittyviä opintoja voidaan suorittaa yksittäisinä kursseina lähinnä Helsingin yliopiston maa- ja metsätaloustieteellisessä ja eläinlääketieteellisessä tiedekunnassa.

Euroopan tasolla on käynnissä pyrkimys hevosalan opintojen ja erikoistumismahdollisuuden kehittämiseen (European Master in Equine Science), mutta suomalaiset eivät tässä työssä ole olleet kovin aktiivisia. Hevosalan tutkimus-, kehittämis-, opetus- ja erilaiset asiantuntijatehtävät tarvitsevat alan yliopistotutkinnon suorittaneita. Jatkossa hevosala tulee ottaa paremmin huomioon myös meillä yliopistotasoisessa opetuksessa ja tutkijakoulutuksessa.

Hevosalan neuvonnalle on lisääntyvä tarve, kuten edellä on käynyt ilmi. Neuvontaa tarvitsevat paitsi yrittäjät ja ammattilaiset, myös harrastajat. Erityisesti on kehitettävä yritysneuvontaa. Eläinten hyvinvointiasiat, rehuntuotanto, ympäristöasiat, työturvallisuus ja rakentaminen mukaan luettuna maanrakennus, ovat niin ikään neuvonnan erikoiskohteita. Neuvontaa on kehitettävä maatalousneuvontaorganisaation ja alan omien asiantuntijaorganisaatioiden yhteistyönä, ja se tarvitsee tuekseen tutkimusta. Jalostusneuvonnasta vastaa tällä hetkellä hevosjalostusta ohjaava Suomen Hippos ry. Tiedonsiirtoon keskittyvät yksiköt ("osaamiskeskukset”) ovat hyvä väylä tutkimuksista tiedottamiseen ja lisäämään pienten yritysten mahdollisuuksia hyödyntää tutkimustuloksia. Koulutus- ja neuvontamateriaalien tuottaminen sopii hyvin niiden toimintaan.

\section{Kirjallisuus}

EPMA - Pari Mutuel Europa. 2009. The economic and social contribution of horseracing in Europe. European Pari Mutuel Association. Belgia 2009. $31 \mathrm{~s}$.

EQUUS2009. Equus2009-seminaari, Uppsala 29. - 30.10.2009. www.equus2009.eu.

Hollmen, M. \& Mäenpää, M. (toim.). 2004. Hevosalan haasteet. Hevosalan haasteet -työryhmä. $13 \mathrm{~s}$.

Kansallinen hevostutkimusohjelma. 2005. Työryhmämuistio MMM 2005: 11, 30 s.

Martin-Päivä, M. \& Mäenpää, M. (toim.). 2007. Hevosalan hanketoiminnan kehittämisohjelma vuosille 2007 - 2013. Suomen Hippos ry. 15 s.

Martin-Rosset, W. 2009. Equine science looking forward to match the challenge of a growing industry. Le Royesitelmä, 60. EAAP-kongressi, Barcelona 24. - 27.8.2009. www.eaap.org.

Pussinen, S., Korhonen, Pölönen, I \& Varkia, R. 2007. Kasvava hevosala - Hevosalan kehitysnäkymiä Suomessa. Laurea-ammattikorkeakoulun julkaisusarja B 19: $91 \mathrm{s.}$

Rummukainen, L. 2006. Hevostalous Hausjärven, Hyvinkään, Lopen ja Riihimäen alueella. Opinnäytetyö Laureaammattikorkeakoulu, Hyvinkää. 59 s.

Talikainen, S. 2004. Hevostalous maatiloilla. MTT:n selvityksiä 67: 90 s.

Thuneberg, T. 2009. Hevosyrittäjänä vuonna 2014. Maataloustieteen Päivät 2010. www.smts.fi

Varkia, R., Pussinen, S. \& Korhonen, J. 2006. Elvyttääkö hevonen maaseudun? Terra 118: 189 - 192. 